\title{
Pathogenicity of entomopathogenic fungi against the aphid and the whitefly species on crops grown under greenhouse conditions in India
}

\author{
Harshdeep Singh ${ }^{1 *}$ and Tanjot Kaur ${ }^{2}$
}

\begin{abstract}
The aphids, Myzus persicae (Sulzer) and Aphis gossypii (Glover) (Hemiptera: Aphididae) and the whiteflies, Trialeurodes vaporariorum (Westwood) and Bemisia tabaci (Gennadius) (Hemiptera: Aleyrodidae) are the most damaging pests of greenhouse crops, which cause vector-borne viral diseases and its damage includes chlorosis, necrosis, and fruit abortion. This review article addresses the protected cultivation of vegetable crops (cucumber, capsicum, tomato, and gerbera), important insect pests of greenhouse crops in India along with its management by entomopathogenic fungi (EPF) and increase in the virulence by different genetically modified techniques. Due to excessive and indiscriminate use of insecticides over the years, these insect pests became resistant to these insecticides. So, there is a need for the effectual substitutes to manage these pests. Biological control is a foundation of integrated pest management (IPM) that plays a key role in the repression of arthropod pests. Among different IPM program, the uses of different microbial formulations are ecofriendly and safe for life and proven a boon for the farmers and entrepreneurs. EPF are the most effective in reducing aphid and whitefly populations on vegetable crops recommending its organic production under greenhouse conditions and could be a part of IPM. In the future, these insect pests will become more resistant to entomopathogens. Some novel techniques such as genetic engineering of fungal formulations will be required to increase the efficiency of various entomopathogens as these techniques are well adopted by countries like the USA, China, and European countries but its use in India and needs to be improved in the near future.
\end{abstract}

Keywords: Protected cultivation, Aphid, Whitefly, Entomopathogenic fungi, Genetic engineering

\section{Background}

In the changing scenario of increasing human population, decreasing cultivable land and water resources, there is a need to produce more food from available land and water. One technology being used in this direction is growing crops under protected cultivation, which has shown enormous potential during the last few decades and is well adopted for vegetable and

\footnotetext{
* Correspondence: harshdeepsingh360@gmail.com

'Department of Microbiology, Punjab Agricultural University, Ludhiana 141004, India

Full list of author information is available at the end of the article
}

ornamental crops. Protected cultivation of vegetable crops hold good for manifold increase in productivity compared to open-field conditions (Singh 2013; Pekkeriet et al. 2015, and Choudhary 2016). In the recent past, there has been a tremendous increase in area under protected cultivation (around 20 million hectares area all over the world). In India, the area under protected cultivation is around 46,000 hectares with productivity of 327 thousand tons, which is mainly confined to Andhra Pradesh, Maharashtra, Karnataka, Himachal Pradesh, Punjab, Haryana, and Rajasthan (Sabir and Singh 2013; Senthilkumar et al. 2018). The 
farmers are growing vegetables, flowers, and other high-value crops under the protected environment and earn high profit. Among the vegetables, capsicum, chili, cucumber, tomato, and brinjal are the main crops grown under protected environment. The productions of these crops are greatly influenced by the insect pests (Vashishth 2009 and Sood et al. 2012a). The whitefly, Trialeurodes vaporariorum (Westwood) and Bemisia tabaci (Gennadius); red spider mite, Tetranychus ludeni (Zacher) and T. urticae (Koch); serpentine leaf miner, Liriomyza trifoli (Burgess); Polyphagotarsonemus latus (Banks); thrips, Franklinella ocidentalis (Pergande); Scirtothrips dorsalis (Hood); tobacco caterpillar, Spodoptera litura (Fabricius) and aphid, Aphis gossypii (Glover) and Myzus persicae (Sulzer) are economic pests infest crops under protected cultivation (Sood et al. 2018; Singh and Joshi 2020). Among these, the aphids, M. persicae and $A$. gossypii (Hemiptera: Aphididae) and the whitefly, T. vaporariorum and B. tabaci (Hemiptera: Aleyrodidae) are the major insect pests, which cause vector borne viral diseases and their damage includes chlorosis, necrosis, wilting, stunting, flower and fruit abortion, leaf distortion, and defoliation (Sayed et al. 2019). Due to the availability of favorable environmental conditions under protected cultivation, the management of these pests is quite challenging. It is mainly done by chemical pesticides but due to excessive and indiscriminate use of these pesticides, insect pests become resistant against them. Additionally, inauspicious effects of chemical insecticide residues on the crop (Van Lenteren 2000), killing of non-target organisms (Pilkington et al. 2010), and development of resistance to pesticides (Sood and Sood 2005; Pappas et al. 2013) are linked with its excessive use.

Various parasitoids, predators, pathogens, and botanicals are being exploited for the management of these pests (Ali et al. 2017 and Ullah et al. 2019). Entomopathogenic fungi (EPF) have been identified as potential control agents against aphids and the whitefly species under protected conditions (Saito and Sugiyama 2005). Beauveria bassiana (Balsamo) Vuillemin, Lecanicillium lecanii (Zimmerman), Metarhizium anisopliae (Metsch.), and Paecilomyces fumosoroseus (Wize) are the key tools for the management of various agricultural insect pests, including whiteflies, mealy bugs, aphids and thrips in outdoor and greenhouse crops (Wraight et al. 2000; Daniel and Wyss 2010; Shah and Shukla 2014).

This review will elucidate the fundamental information on the crops grown under protected conditions; discuss major insect pests of crops grown under protected cultivation in India along with its management with the use of different commercial and indigenous fungal formulations and genetically engineered entomopathogens.

\section{Protected cultivation of vegetable crops in India}

The concept of protected cultivation came into existence in seventeenth century when natives of Netherlands and England used artificial structures (similar to polyhouse structures) to produce the crop under adequate climatic conditions (Janick et al. 2007). In today's world, the Netherlands is forefront in the production of largecapacity polyhouses to enhance the crop yield and quality (Muijzenberg and Erwin 1980). The adoption of new agricultural techniques is foremost in the agriculture leading countries to produce the crop with high quality and revenue from low-cost investment. The uses of various agricultural approaches put India out of frontier (Navale et al. 2003 and Kanzaria et al. 2017). The protected cultivation includes growing crops under polyhouse, greenhouse, net house which are made up of materials like acrylic, polycarbonate, polyethylene which help to protect the crops from environmental factors. Nowadays, India is becoming popular for protected cultivation among the farmers and entrepreneurship because of its profitability and sustainability. Protected cultivation is the most important way to produce a large variety of horticultural crops, including tomato, capsicum, cucumber, and other vegetable crops (Sabir and Singh 2013). Under protected conditions, various factors like temperature, humidity, light, soil, and water are controlled. Additionally, the economics of capsicum under protected cultivation was studied by Sreedhara et al. (2013) and they revealed that India contributes onefourth of world production of capsicum with an average annual production of 0.9 million tons from an area of 0.885 million hectares with a productivity of $1266 \mathrm{~kg}$ per hectare and out of total production; Andhra Pradesh stands first with production of 748.5 thousand tons followed by Karnataka from an area of 76 thousand hectares with a productivity of 131 thousand tons. Weintraub (2007) explained that when IPM is employed properly, it had the advantage of eliminating some open field pests, thereby results in increasing fruit yields. The performance of crops grown under open and protected cultivation was studied and observed that capsicum grown under protected conditions enhanced the yield of a crop by $49.8 \mathrm{MT} / \mathrm{ha}$ than open-field cultivation (18.34 $\mathrm{MT} / \mathrm{ha}$ ) (Ngullie and Biswas 2016). The performance and economics of crop varieties are almost thrice in protected conditions as compared to open field conditions (Singh et al. 2011) due to the protective ability of greenhouses.

\section{Abundances of aphid and whitefly species on crops grown under protected cultivation in India Whiteflies}

Whiteflies are the devastating pests of vegetables, ornamentals, and field crops throughout the tropical, subtropical, 
and temperate regions of the world. More than 1420 species of whiteflies associated with agricultural crops throughout the world. Among different species of whiteflies, $B$. tabaci being one of the most widely distributed pests found in tropical and subtropical regions of the world, where it infests over 600 different cultivated and wild plant species from 63 plant families (Oliveira et al. 2001). In India, B. tabaci was first recorded on cotton at Pusa (Bihar) in 1905 (Misra and Lamba 1929). Seventeen plant whitefly species belonging to widely separate families were reported in the Kalyani area of West Bengal. In Andhra Pradesh, B. tabaci was found to survive on 14 off-season hosts (Verma et al. 1989). Later, (Arneja 2000) from Punjab reported B. tabaci from 16 different host plants comprising field crops, vegetables, and weeds. Konar during (1997) also observed the three species of Aleyrodidae associated with Citrus reticulate (mandarin) orchards in the Darjeeling district of West Bengal. Whereas, in Lakshadweep (Dubey et al. 2004) reported the occurrence of 12 species of whiteflies representing 11 genera. From Himachal Pradesh, (Bhalla and Pawar 1977) recorded 10 species of whiteflies belonging to 6 genera. Bemisia tabaci was recorded on crops such as Capsicum annum, Cucumis sativus, Lycopersican esculentum, Gerbera jamesonii, and Solanum melongena in different regions of India (Reddy and Kumar 2006; Sood and Sharma 2010; Ibrahim et al. 2011; Kumar et al. 2017; and Padhi et al. 2017; Khanzada et al. 2018) (Table 1). In India, the incidence of $T$. vaporariorum was recorded first at Thummantty in the Nilgiri hills of Tamil Nadu and Himachal Pradesh on crops such as potato, capsicum, tomato, and cucumber (David 1971; Sharma et al. 2006; Sood et al. 2006; Vashisth 2009; Sood et al. 2012b; Sood and David 2012). So far, It has been reported on 120 host plants belonging to 38 plant families, mainly Solanaceae (15 species), Compositae (17 species), Labiatae (8 species), Acanthaceae (7 species), Leguminosae and Onagraceae (6 species each), and Malvaceae and Verbenaceae (5 species each) from different parts of India (Mohan et al. 1988; Krishnan and David 1999, and Bakshi et al. 2003).

The wide range of aleyrodid fauna, B. tabaci and T. vaporariorum has drawn the maximum attention due to their wider host range and the losses incurred. Bemisia tabaci is distributed in the warmer regions Byrne and Bellows (1991) whereas T. vaporariorum is a serious pest in temperate region under glasshouses and field crops with summer region (Hill 1987). It is a serious pest in temperate regions under protected cultivation situations and in field crops where the summers are warm enough. It is considered as a "New World" species having distribution throughout Europe, parts of Africa, Asia, Australasia, North America, and South America (Hill 1987). Moreover, the infestation of greenhouse whitefly occurs in 249 host plants from 84 families of different crops and ornamental plants in temperate regions from six continents Russell (1977). The whitefly breeds were found throughout the year and it completes 13 generations in a year under protected environment in India (Sood et al. 2014). Adults of T. vaporariorum are tiny (1 mm long) snowy whiteflies with a covering of white waxy powder on wings. They are mostly found on the under surface of the leaves (Hill 1987). One hundred and fourteen virus species are transmitted by whiteflies (Aleyrodidae). Whiteflies, B. tabaci, and T. vaporariorum transmits 111 and 3 species, respectively. Of the whitefly-transmitted virus species, $90 \%$ belongs to the Begomovirus genus, $6 \%$ belongs to the Crinivirus genus, and the remaining $4 \%$ belongs to the Closterovirus, Ipomovirus, and Carlavirus genera (Jones 2003). The host plants were found to have a pronounced effect on the selection, feeding, oviposition, and development of whitefly. Overall, the yield loss due to various insect pests ranged from $30-40 \%$ among different vegetable crops in India (Sharma et al. 2017). However, loss due to whitefly under protected conditions varies among different vegetables. In capsicum, whitefly, B. tabaci caused $13.60 \%$ yield loss (Singh H and Joshi N 2020) whereas, on cucumber plant yield loss was approximately $26 \%$ (Ghongade 2020). Moreover, whitefly caused 54\% yield loss in okra plant (Dhandapani et al. 2003). The development of the whitefly was seen higher on eggplant and cucumber, followed by tomato whereas slow on capsicum crop (Kamp and Lenteren 1981). Research indicated

Table 1 List of aphid and whitefly species recorded under protected conditions in different regions of India

\begin{tabular}{|c|c|c|c|}
\hline Species & Host plants & Location & Author and year \\
\hline $\begin{array}{l}\text { Aphis } \\
\text { gossypii }\end{array}$ & $\begin{array}{l}\text { Capsicum annum, Cucumis sativus, and } \\
\text { Lycopersican esculentum }\end{array}$ & Punjab, New Delhi & Kaur (2005), Ibrahim et al. (2011), Khanzada et al. (2018) \\
\hline $\begin{array}{l}\text { Myzus } \\
\text { persicae }\end{array}$ & $\begin{array}{l}\text { Capsicum annum, Cucumis sativus, and } \\
\text { Gerbera jamesonii }\end{array}$ & $\begin{array}{l}\text { Punjab, Maharashtra, and } \\
\text { Himachal Pradesh }\end{array}$ & $\begin{array}{l}\text { Singh et al. (2003), Singh et al. (2004), Gavkare et al } \\
\text { (2014), Ibrahim et al. (2011), Weintraub (2007), Javed } \\
\text { et al. (2019) }\end{array}$ \\
\hline $\begin{array}{l}\text { Bemisia } \\
\text { tabaci }\end{array}$ & $\begin{array}{l}\text { Capsicum annum, Cucumis sativus, } \\
\text { Lycopersican esculentum Gerbera jamesonii, } \\
\text { and Solanum melongena }\end{array}$ & $\begin{array}{l}\text { Karnataka, Punjab, Himachal } \\
\text { Pradesh, Uttar Pradesh, and } \\
\text { West Bengal }\end{array}$ & $\begin{array}{l}\text { Singh et al. (2003), Reddy and Kumar (2006), Ibrahim } \\
\text { et al. (2011), Khanzada et al. (2018), Kumar et al. (2017), } \\
\text { Padhi et al. (2017) }\end{array}$ \\
\hline $\begin{array}{l}\text { Trialeurodes } \\
\text { vaporariorum }\end{array}$ & $\begin{array}{l}\text { Capsicum annum, Cucumis sativus, } \\
\text { Lycopersican esculentum, and Gerbera } \\
\text { jamesonii }\end{array}$ & $\begin{array}{l}\text { Tamil Nadu and Himachal } \\
\text { Pradesh }\end{array}$ & $\begin{array}{l}\text { Vashisth (2009), Sood et al. (2012), Sharma et al. 2006, } \\
\text { Chinniah et al. } 2016\end{array}$ \\
\hline
\end{tabular}


that the whitefly prefers tobacco, cucumber, broad bean, and cowpea significantly more than paprika with more probing time on preferred hosts (Xu et al. 1994).

\section{Aphids}

The aphid species, M. persicae and A. gossypii are the most damaging insect pests of crops grown under protected conditions across the world because of their ability to transmit viruses to the plants. Their damage includes chlorosis, necrosis, fruit abortion, and stunted growth (Perdikis et al. 2008). Myzus persicae caused $19.43 \%$ yield loss on vegetable crops under protected cultivation in India (Singh and Joshi 2020). However, on an average, damage caused by insect pests under protected conditions on various crops ranged from 15-37\% (Dhandapani et al. 2003; Rathee and Dalal 2018). Damage caused by aphid species on chili crops was recorded as $38.85 \%$ (Chinniah et al. 2016). More than 500 species of $M$. persicae are known to kill various host plants all around the world. In India, M. persicae is recorded in various regions of Punjab, Himachal Pradesh, and Maharastra on crops capsicum, cucumber, tomato, and Gerbera ( Singh et al. 2004; Weintraub 2007; Vashisth 2009; Ibrahim et al. 2011; Sood et al. 2012; Sabir et al. 2013; Gavkare et al. 2014; and Javed et al. 2019) (Table 1). As reported by Vasicek et al. (2001), among the most important pests of pepper (Capsicum annuum) crop in Argentina, the aphids stand out, of which $M$. persicae is the key pest, followed by Aphis solani and Macrosiphum euphorbiae. The glasshouse provides the best condition for the development of aphid population. Greenhouse crops are susceptible to infestation by no. of insects like aphid, whitefly, mites, and thrips that cause yield loss and crop damage. In India, capsicum is an important vegetable crop. Capsicum annum and $C$. frutescens, family Solanaceae are the two capsicum species extensively cultivated in tropic and sub tropic regions. The population dynamics of sucking pests and their correlation with weather on capsicum was studied and result showed an incidence of aphid A. gossypii on capsicum crop under protected conditions (Meena et al. 2013). Aphis gossypii is the most abundant in Punjab and New Delhi regions on Capsicum annum, Cucumis sativus, and Lycopersican esculentum (Singh et al. 2004; Kaur 2005; Ibrahim et al. 2011, and Nagamandla et al. 2017) It was observed in West Bengal region along with other insect pests on tomato under protected conditions and cause various vector-borne diseases. It is observed that the majority of the aphids and whiteflies species are observed in the northern and southern regions of India.

\section{Biological control by entomopathogenic fungi}

Entomopathogenic fungi (EPF) are bioinsecticides with an ability to infect and kill arthropods. They are isolated from the naturally occurring soil and arthropod carcasses (Behie and Bidochka 2014; Litwin et al. 2020). These fungi belong to 6 fungal classes: Basidiomycota, Entomophtoromycota, Oomycetes, Chytridiomycota, Microsporidia, and Ascomycota. Until now, 238 species of Basidiomycota, 474 species of Entomophtoromycota, 12 species of Oomycetes, 65 species of Chytridiomycota, 339 species of Microsporidia, and 476 species Ascomycota were reported (Araujo and Hughes 2016). However, species of Ascomycota and Entomophtoromycota are more often in natural habitat. Metarhizium spp. (Metschnikoff) Sorokin are ubiquitous naturally occurring soil-inhabiting fungi (Meyling et al. 2011). In 1888, Elie Metchnikoff, a Russian microbiologist firstly discovered the EPF and named it as Metarhizium anisopliae. In 1965, Boverin, a Beauveria bassiana based mycoinsecticide was developed to control the Colorado potato beetle and codling moth (Litwin et al. 2020). Verticillium lecanii (Zimmerman) Viégas (reclassified as Lecanicillium lecanii (Petch) Zare and Gams as an insect pathogen that is used commercially to control greenhouse pests (Cuthberston and Walter 2005).

Strains of entomopathogenic fungi are concentrated in the following orders: Hypocreales (various genera), Onygenales (Ascosphaera genus), Entomophthorales, and Neozygitales (Entomophthoromycota). Entomopathogens are the most important biological agents that can occur as epizootic or enzootic levels in their host populations (Mora et al. 2017). Entomopathogens are being reported to control various crops insect pests. These EPF viz. Beauveria bassiana (Hypocreales: Cordycipitaceae), M. anisopliae (Hypocreales: Clavicipitaceae), Lecanicillium spp., (previously Verticillium lecanii (Hypocreales: Cordycipitaceae), and I. fumosorosea (Hypocreales: Clavicipitaceae) (previously Paecilomyces fumosoroseus) are reported to kill insect by nutritional deficiency, the release of adhesions (MAD1 and MAD2), secondary metabolites, tissue degradation, and release of toxins. The EPF contain cuticle degrading enzymes like protease; lipase and chitinase which degrade the insect cuticle, followed by penetration of fungal germ tube into insect body and thereby release of several mycotoxins such as Beauvericin, Beauverolides, Bassianolide to kill the insect (Gabarty et al. 2014; Skinner et al. 2014; Lacey et al. 2015). It has been reported that $B$. bassiana and $M$. robertsii provides plant with nitrogen during insect parasitization, thus encourages plant growth (Behie and Bidochka 2014).

\section{Virulence of entomopathogenic fungi against whitefly}

All biopesticides containing insect pathogen B. bassiana, $V$. lecanii, and $M$. anisopliae were found effective in reducing the pest population. But the organic products and mineral oils were comparatively less effective. Therefore, a study 
was conducted to evaluate EPF against B. tabaci and $T$. vaporariorum, and obtained result showed that $L$. lecanii was more effective against $B$. tabaci and $T$. vaporariorum causing 89.3 to 96 and 79.3 to $95.6 \%$ mortality, respectively under greenhouse conditions. In addition to this, the infectious and epizootic potential of $P$. fumosoroseus on the susceptibility of $B$. argentifolii were not affected by the host vegetable species of tomato (Vidal et al. 1998). However, mortality was $>70 \%$, the first week after treatment and increased further in the second week. Lecanicillium lecanii caused $86 \%$ mortality of $B$. tabaci on brinjal at 5 days after treatment (Phadke and Phadke 2000). Besides this, B. bassiana and $P$. fumosoroseus have strong potential for microbial control of nymphal whiteflies infesting cucurbit crops (Wraight et al. 2000). Thirty-five strains of $L$. lecanii originated from different hosts and geographical locations were tested as potential biocontrol agents against silver leaf whitefly, B. argentifolii (Gindin et al. 2000). Pathogenicity of B. bassiana (strain GHA, lot TGAI 97-10-1) and P. fumosoroseus (strain 612, lot 940917) with conidial concentration of $1.4 \times 10^{11}$ and $1.8 \times 10^{11}$ conidia/ml were tested against the 3rd-instar nymphs of $T$. vaporariorum reared on cucumber and tomato plants. Nymphs were highly susceptible to infection by both fungi after a one-time application of conidia onto cucumber plants. In contrast, insects reared on tomato plants were significantly less susceptible to infection (Poprawski et al. 2000). The whitefly mycoinsecticide products based on L. lecanii, P. fumosoroseus, and B. bassiana have the capacity to suppress and in some instances, provide good control of whiteflies in both greenhouse and field crops. Development of methods and strategies to enhance mycoinsecticide efficacy has been attempted and primarily focus on initiating treatments against the early stages of the pest to prevent population build up, targeting pest populations developing under moderate environmental conditions (e.g., during spring or fall growing seasons), selecting crops amenable to multiple, highly efficient spray applications and applying fungi asynchronously with incompatible fungicides (Faria and Wraight 2001). Pathogenicity of commercial EPF L. muscarium (Mycotal, Koppert Biological Systems Ltd, UK) was evaluated on sweet potato whitefly $B$. tabaci under laboratory and glasshouse cultivation and recorded that the application of $L$. muscarium against $B$. tabaci resulted in a significant increase in the mortality of $B$. tabaci under glasshouse cultivation and also no plant damage was recorded during the experiment (Cuthbertson and Walters 2005). Furthermore, the EPF $L$. lecanii caused 26.6 to $76.6 \%$ mortality against $T$. vaporariorum 7 days post treatment when applied with the concentration of $1 \times 10^{7}$ conidia/ml as reported by (Scorsetti et al. 2008). The efficacy of different bio-pesticide was reported against whitefly $B$. tabaci on tomato plant and result showed that biopesticides viz. Bio Magic (91.64\%), Mealikil (93.55\%), and Biopower (88.91) were highly effective in killing the nymphal whitefly population over control after 3rd spray (Budha et al. 2015). Some of the commercially available biopesticides are shown in Table 2. The most effective EPF that reduced the pest population were B. bassiana, $V$. lecanii, and $M$. anisopliae that was evaluated at three different concentrations $(1 \times$ $10^{7}, 1 \times 10^{8}$, and $1 \times 10^{9}$ spores $/ \mathrm{ml}$ ) against B. tabaci in laboratory and field cultivation, respectively (Abdel-Rahim and Ahmed 2017). They reported that the highest concentration $\left(1 \times 10^{9}\right.$ spores $\left./ \mathrm{ml}\right)$ of the 3 EPF was highly toxic to adults of $B$. tabaci than the others. Under field cultivation also highest concentration $\left(1 \times 10^{9}\right.$ spores $\left./ \mathrm{ml}\right)$ of $V$. lecanii was the best in managing the adult whitefly population.

Table 2 Commercial bioformulations for the management of aphid and whitefly species under protected conditions in India

\begin{tabular}{|c|c|c|c|c|}
\hline Active ingredient and concentration & $\begin{array}{l}\text { Brand } \\
\text { name }\end{array}$ & Target pests & Crops & Manufacturer \\
\hline $\begin{array}{l}\text { Beauveria bassiana } 1.50 \%\left[1 \times 10^{8} \mathrm{CFU} /\right. \\
\mathrm{ml}]\end{array}$ & Bio-Power & $\begin{array}{l}\text { Aphids, whiteflies, mites, and } \\
\text { thrips }\end{array}$ & $\begin{array}{l}\text { Cabbage, Capsicum, } \\
\text { Tomato }\end{array}$ & $\begin{array}{l}\text { T. Stanes and Company } \\
\text { Limited, India }\end{array}$ \\
\hline $\begin{array}{l}\text { Lecanicillium lecanii 1.50\% [1 × } 10^{8} \text { CFU/ } \\
\mathrm{ml}]\end{array}$ & Bio-Catch & Whiteflies, aphids, mealybugs & Several crops & $\begin{array}{l}\text { T. Stanes and Company } \\
\text { Limited, India }\end{array}$ \\
\hline $\begin{array}{l}\text { Metarhizium anisopliae } 1.50 \%\left[1 \times 10^{8}\right. \\
\text { CFU/ml] }\end{array}$ & Bio-Magic & $\begin{array}{l}\text { Borer, termites, leaf hoppers, and } \\
\text { aphids }\end{array}$ & Rice, Capsicum & $\begin{array}{l}\text { T. Stanes and Company } \\
\text { Limited, India }\end{array}$ \\
\hline $\begin{array}{l}\text { Beauveria bassiana } 2.0 \% \text { strain IPL/BB/Ml/ } \\
01\left[2 \times 10^{8} \mathrm{CFU} / \mathrm{ml}\right]\end{array}$ & Daman & Sucking pests, caterpillars & Greenhouse crops & $\begin{array}{l}\text { International Panaacea } \\
\text { Limited, India }\end{array}$ \\
\hline $\begin{array}{l}\text { Verticillium lecanii } 2.0 \% \text { strain IPL/NL/05 [2 } \\
\left.\times 10^{8} \mathrm{CFU} / \mathrm{ml}\right]\end{array}$ & Varunastra & $\begin{array}{l}\text { Whiteflies, aphids, thrips, and } \\
\text { scale insects }\end{array}$ & $\begin{array}{l}\text { Capsicum, cucumber, } \\
\text { tomato and brinjal }\end{array}$ & $\begin{array}{l}\text { International Panaacea } \\
\text { Limited, India }\end{array}$ \\
\hline $\begin{array}{l}\text { Metarhizium anisopliae } 1.0 \% \text { strain IPL/KC/ } \\
44\left[1 \times 10^{8} \mathrm{CFU} / \mathrm{g}\right]\end{array}$ & Kalichakra & $\begin{array}{l}\text { Beetles, grasshoppers, and } \\
\text { aphids }\end{array}$ & All crops & $\begin{array}{l}\text { International Panaacea } \\
\text { Limited, India }\end{array}$ \\
\hline $\begin{array}{l}\text { Beauveria bassiana strain 63428-82-0 }[1 \times \\
\left.10^{9} \mathrm{CFU} / \mathrm{g}\right]\end{array}$ & Biosoft & Sucking pests & Capsicum, cabbage, cotton & $\begin{array}{l}\text { Agriland Biotech Limited, } \\
\text { India }\end{array}$ \\
\hline $\begin{array}{l}\text { Beauveria bassiana NCIM/1216 ATCC } \\
26851\left[1 \times 10^{8} \mathrm{CFU} / \mathrm{ml}\right]\end{array}$ & Racer & $\begin{array}{l}\text { Spodoptera litura, caterpillars, } \\
\text { mealybugs, aphids }\end{array}$ & Several horticultural crops & $\begin{array}{l}\text { Agrilife Biosolutions for soil } \\
\& \text { crops, India }\end{array}$ \\
\hline
\end{tabular}

Data source: (Ramanujam et al. 2014; Chinniah et al. 2016; Mascarin and Jaronski 2016 and Ruiu L 2018; Singh and Joshi 2020) 


\section{Virulence of entomopathogenic fungi against aphid}

Twelve different strains of EPF, viz., L. lecanii, P. farinosus, B. bassiana, M. anisopliae, Cordyceps scarabaeicola, and Nomuraea rileyi (Hypocreales: Clavicipitaceae) were evaluated against aphids on cabbage and cucumber crops grown under greenhouse conditions. Among these EPF's, L. lecanii 41185 strain was highly virulent than all other strains against $M$. persicae and $A$. gossypii because it germinates and grew well under a wide range of temperature and humidity as reported by Vu et al. (2007). Beauveria bassiana was used for the control of $M$. persicae on cabbage and it caused 76-83\% mortality in 4 weeks after spray (Filho et al. 2011). While native isolate of B. bassiana caused $100 \%$ mortality 7 days post treatment against $M$. persicae (Ibrahim et al. 2011). Aphids are the most destructive pests in crop production such as pepper and cucumber (Kim et al. 2013). They conducted a bioassay with 47 fungal culture filtrates (three isolates of Isaria spp., and Lecanicillium spp., 20 isolates of B. bassiana and 20 isolates of Cordeceps spp.) in order to evaluate the potential of secondary metabolites produced by entomopathogenic fungi for aphid control. Among 47 culture filtrates cultured potato dextrose broth, filtrate of B. bassiana $\mathrm{Bb} 08$ at $1 \mathrm{ml}$ concentration showed the highest mortality (78\%) against green peach aphid 3 days post treatment. Filtrate of Bb08 cultured in Adamek's medium showed a toxicity of $100 \%$ to 3 rd instar nymphs of the aphid compared with 7 other filtrates cultured in different broths and results indicated that the fungal culture fluid or culture filtrate of B. bassiana Bb08 cultured in Adamek's medium had potential for development as a mycopesticide for aphid control. Interestingly, among different tested conidial bioformulation against $A$. gossypii and $M$. persicae, maximum percent reduction was found by $B$. bassiana isolate JW-1with 98-100\% mortality (Jandricic et al. 2014). Additionally, it was observed that 2 strains of $B$. bassiana and 1 strain of $L$. lecanii against $M$. persicae caused maximum mortality after 10 days post treatment with maximum of $95 \%$ and minimum of $87 \%$ with B. bassiana and L. lecanii, respectively (Nazir et al. 2019). Reseach studies on the effect of EPF showed that mortality caused by $L$. lecanii formulation is significantly better than $M$. anisopliae and B. bassiana against $M$. persicae and A. gossypii under laboratory and greenhouse cultivations. Four procured native isolates of B. bassiana, M. anisopliae, L. lecanii, and Chaetomium globosum and recorded for efficacy against the aphids M. persicae and A. gossypii and results showed that $L$. lecanii showed higher mortality than all 3 isolates against $M$. persicae and A. gossypii under laboratory as well as under greenhouse cultivations, when applied at the concentration of $1 \times 10^{8}$ conidia/ml (Mohammed et al. 2018). Beauveria bassiana and L. lecanii were more virulent entomopathogens for the management of $M$. persicae (Javed et al. 2019).

\section{Increased virulence by genetically engineered methods}

The release of the cuticle enzyme was low during the initial penetration $\mathrm{t}$ and high during the degradation of protein (St. Leger et al. 1996). Beauveria bassiana and M. anisopliae caused infection against insect pests through their cuticle by release of cuticle degrading enzymes.

By the use of phage display technology, hydrophobins were isolated from the culture of B. bassiana. Furthermore, cDNA library was built up by using RNA, in the presence of insect pests. Hydrophobins appears should be selectively enriched by melibiose agarose beads, which further yield two (hyd 1 and hyd 2) different hydrobhobin proteins. Results revealed that hyd 1 gene expressed well in aerial conidia, in vitro blastospores, submerged conidia, and cells sporulating on chitin and insect cuticle in contrast to hyd 2 gene (Cho et al. 2007). Additionally, modification of cuticle degrading and adhesion toxin intestinespecific virulence factor (Vip3Aa1) into B. bassiana isolate BbV28 in the cabbage transgenic plant against $S$. litura aids in digestion in the cytoplasm of insect after 18 to $36 \mathrm{~h}$ of conidial infection (Qin et al. 2010).

Systematically disruption of $\mathrm{Cag} 8$ gene is one of the alternative ways to increase the expression of gene Mrku70 (Xu et al. 2014) that helps to increase the pathogenicity of $M$. robertsii ARSEF 2575 by $93 \%$ as compared to wild type (7\%). Insect cuticle is mainly composed of chitin fibrils, to penetrate this barrier fungus produce chitin degrading enzyme such as proteases and chitinases (Zhao et al. 2016). Over expression of $\operatorname{Pr} 1 A$ enzyme in $M$. robertsii and CDEP1 Bbchit1 in B. bassiana can lead to increase the virulence of these fungi against major crop pests. Genes along with metabolic pathways to increase the virulence are described in Table 3.

\section{Conclusion}

Protected cultivation or greenhouse cultivations would be the modern approach to produce vegetable crops qualitatively and quantitatively in India. Due to the availability of favorable environmental conditions, various insect pests cause acute to severe crop damages under

Table 3 Modified genes along with their metabolic pathways to increase the pathogenicity

\begin{tabular}{lll}
\hline Modified genes & Metabolic pathway & Fungal species \\
\hline $\operatorname{Pr}$ 1A & Protease & Metarhizium robertsii \\
CDEP 1 & Subtilism-like protease & Beauveria bassiana \\
Bbchit 1 & Chitinase & Beauveria bassiana \\
Mr-Npc 2a & Sterol carrier & Metarhizium robertsii \\
ATM 1 & Trehalase & Metarhizium acridium \\
BbBqrA & Benzoquinone oxidoreductase & Beauveria bassiana \\
\hline
\end{tabular}

Data source (Zhao et al. 2016 and Romeis et al. 2019) 
protected cultivations. Aphids and whiteflies are the major insect pests of crops grown under protected cultivations. The use of entomopathogenic fungi (EPF) is one of the alternatives to control various insect pests in India over a few decades. In the future, some novel techniques are required to increase the efficiency of various entomopathogens. Techniques like genetically engineering and cDNA probe will be one of the appropriate ones to decrease pest resistance. These techniques are well adopted by countries like the USA, China, and European countries but its use is limited in India and need to be improved in the near future.

\section{Abbreviations}

EPF: Entomopathogenic fungi; GE: Genetically engineered; IPM: Integrated pest management; CFU: Colony forming unit

\section{Acknowledgements}

Authors are thankful to Dr. Neelam Joshi, Principal Microbiologist, Department of Entomology, Punjab Agricultural University, Ludhiana for his valuable suggestions during the present study.

\section{Authors' contributions}

The first author, H S collected the information mentioned in the tables from different sources, edited the paper and remove errors and grammatical mistakes, and written the manuscript. T K prepared Table 2 and topic with heading increase virulence by genetically engineered methods and made necessary corrections. All authors read and approved the final manuscript.

\section{Funding}

Not applicable

\section{Availability of data and materials}

Data collected from different sources during this study are included in this article.

\section{Ethics approval and consent to participate}

Not applicable

\section{Consent for publication}

Not applicable

\section{Competing interests}

The authors declare that they have no competing interests.

\section{Author details}

${ }^{1}$ Department of Microbiology, Punjab Agricultural University, Ludhiana 141004, India. ${ }^{2}$ B. tech (Biotechnology), Sri Guru Granth Sahib World University, Sahib, Fatehgarh 140407, India.

Received: 22 May 2020 Accepted: 23 June 2020

Published online: 06 July 2020

\section{References}

Abdel-Rahim MA, Lamya Ahmed AK (2017) Virulence of three entomopathogenic fungi against whitefly, Bemisia tabaci (Gennadius) (Hemiptera: Aleyrodidae) in tomato crop. J Entomol 14:155-159

Ali S, Ullah Ml, Arshad M, Iftikhar Y, Saqib M, Afzal M (2017) Effect of botanicals and synthetic insecticides on Pieris brassicae (L., 1758) (Lepidoptera: Pieridae). Turkish J Entomol 41(3):275-284

Araujo JPM, Hughes DP (2016) Diversity of entomopathogenic fungi which groups conquered the insect body? In: Lovett B, Leger RJS (eds) Advances in genetics, vol 94. Elsevier, Amsterdam, pp 1-39. https://doi.org/10.1016/bs. adgen.2016.01.001

Arneja AK (2000) Biology of whitefly, Bemisia tabaci (Gennadius) on American cotton. Punjab Agricultural University, Ludhiana, India, M.Sc. thesis
Bakshi AK, Chauhan U, Sharma KC, Gupta YC (2003) Host range of the greenhouse whitefly T. vaporariorum (Westwood) (Homoptera: Aleyrodidae) in mid-hill regions of Himachal Pradesh. Insect Environ 9:55-56

Behie SW, Bidochka MJ (2014) Ubiquity of insect-derived nitrogen transfer to plants by endophytic insect-pathogenic fungi: an additional branch of the soil nitrogen cycle. Appl Environ Microbiol 80:1553-1560

Bhalla O P and Pawar A D (1977) A survey study of insect and non-insect pests of economic importance in Himachal Pradesh. Tiku and Tiku, Kitab Mahal, 192-D. N. Road, Bombay400 001(India).

Budha PB, Sharma M, Pradhan SB (2015) Efficacy test of bio-pesticides against tobacco whitefly Bemisia tabaci (Gennadius, 1889) on tomato plants in Nepal. J Inst Sci Tech 20(2):11-17

Byrne DN, Bellows TS (1991) Whitefly biology. Annu Rev Entomol 36:431-457

Chinniah C, Ravikumar A, Kalyanasundaram M, Parthiban P (2016) Management of sucking pests, by integration of organic sources of amendments and foliar application of entomopathogenic fungi on chili. J Biopest 9(1):34-40

Cho EM, Kirkland BH, Holder DJ, Keyhani NO (2007) Phage display cDNA cloning and expression analysis of hydrophobins from the entomopathogenic fungus Beauveria (Cordyceps) bassiana. Microbiol 153:3438-3447

Choudhary AK (2016) Scaling-up of protected cultivation in Himachal Pradesh, India. Curr Sci 111:272-277

Cuthbertson AGS, Walters KFA (2005) Pathogenicity of the entomopathogenic fungus, Lecanicillium muscarium, against the sweet potato whitefly Bemisia tabaci under laboratory and glasshouse cultivation. Mycopathologia 160:315319

Daniel C, Wyss E (2010) Field applications of Beauveria bassiana to control the European cherry fruit fly Rhogoletis cerasi. J Appl Entomol 134:9-10

David BV (1971) Studies on south Indian aleyrodidae. Tamil Nadu Agricultural University, Coimbatore, India, Ph.D. dissertation

Dhandapani N, Shelkar UR, Murugan M (2003) Bio-intensive pest management (BIPM) in major vegetable crops. J Food Agric Environ 1(2):333-339

Dubey AK, Regu K, Sundararaj R (2004) Aleyrodid (Hemiptera: Aleyrodidae) fauna of the Lakshadweep, India. Entomon 29:279-286

Fariaa M, Wraight SP (2001) Biological control of Bemisia tabaci with fungi. Crop Prot 20:767-778

Filho MM, Oliveira S, Liz RD, Faria M (2011) Cage and field assessments of Beauveria bassiana- based Mycoinsecticides for Myzus persicae Sulzer (Hemiptera: Aphididae) control in cabbage. Neotrop Entomol 40(4):470-476

Gabarty A, Salem HM, Fouda MA, Abas AA, Ibrahim AA (2014) Pathogenicity induced by the entomopathogenic fungi Beauveria bassiana and Metarhizium anisopliae in Agrotis ipsilon (Hufn.). J Rad Res Appl Sci 7(1):95100

Gavkare O, Surjeet K, Yuvraj S, Bhopale SP (2014) Abundance of the Myzus persicae (Sulzer) under protected environment in Himachal Pradesh, India. J Ind Pollut Control 30(2):285-287

Ghongade DS (2020) Population abundance and management of whitefly and red spider mite on parthenocarpic cucumber grown under protected conditions. Punjab Agricultural University, Dissertation

Gindin G, Geschtovt NU, Raccah B, Barash I (2000) Pathogenicity of Verticillium lecanii to different developmental stages of the silverleaf whitefly, Bemisia argentifolii. Phytoparasitica 28:229-239

Hill D S (1987) Agricultural insect pests of temperate regions and their control. pp 654-59, Cambridge University Press, London, UK.

Ibrahim L, Hamieh A, Ghanem H, Ibrahim SK (2011) Pathogenicity of entomopathogenic fungi from Lebanese soils against aphid, whitefly and non-target beneficial insects. Int J Agr Sci 3(3):156-164

Jandricic SE, Filotas MM, Sanderson JP, Wraight SP (2014) Pathogenicity of conidia-based preparations of entomopathogenic fungi against the greenhouse pest aphids Myzus persicae, Aphis gossypii, and Aulacorthum solani (Hemiptera: Aphididae). J Invertebr Pathol 118:34-46

Janick J, Paris HS, Parrish DC (2007) The cucurbits of Mediterranean antiquity: identification of taxa from ancient images and descriptions. Annuals of Botany. 100:1441-1457

Javed K, Javed H, Mukhtar T, Qiu D (2019) Pathogenicity of some entomopathogenic fungal strains to green peach aphid, Myzus persicae Sulzer (Homoptera: Aphididae). Egypt J Biol Pest Control. 29(92):1-7

Jones DR (2003) Plant viruses transmitted by whiteflies. European J Plant Pathol 109:195-219

Kanzaria DR, Patel HN, Vaghasia M, Malam VR, Chitroda RL, Barad HR, Halepotara F, Solanki M (2017) Capsicum and tomato production potentials under protected conditions. Trends in Biosciences 10(15):2612-2614 
Kaur S (2005) Management of aphids. Aphis gossypii Glover on chili in polyhouse. Indian J. Ecol 32:241-242

Khanzada KK, Khanzada B, Chandio RH, Sipio FA, Jat MI (2018) Evaluation of insecticides against insect-pests on chilies. Capsicum annum L. and their management. Int J Zool Stud 3(5):12-15

Kim JJ, Jeong G, Han JH, Lee S (2013) Biological control of aphid using fungal culture and culture filtrates of Beauveria bassiana. Mycobiology 41(4):221-224

Konar A (1997) Incidence pattern of whiteflies on orange, Citrus reticulata Blanco in different orchards of Darjeeling District, West Bengal. Environment and Ecology. 15(4):797-799

Krishnan B, David BV (1999) Occurrence of greenhouse whitefly, Trialeurodes vaporariorum Westwood on the Nilgiris, India. J Appl Zool Res 3:201

Kumar A, Sachan SK, Kumar S, Kumar P (2017) Efficacy of some novel insecticides against whitefly (Bemisia tabaci Gennadius) in Brinjal. J Entomol Zool Stud 5(3):424-427

Lacey LA, Grzywacz D, Shapiro-llan DI et al (2015) Insect pathogens as biological control agents: back to the future. J Invertebr Pathol 132:1-41. https://doi. org/10.1016/j.jp. 2015.07 .009

Litwin A, Nowak M, Rozalska S (2020) Entomopathogenic fungi: unconventional applications. Rev Environ Sci Biotechnol 19:23-42. https://doi.org/10.1007/ s11157-020-09525-1

Mascarin GM, Jaronski ST (2016) The production and uses of Beauveria bassiana as a microbial insecticide. World J Microbiol Biotech 32(11):1-26

Meena RS, Ameta OP, Meena BL (2013) Population dynamics of sucking pest and their correlation with weather parameters in chili Capsicum annum L. J Life Sci 8(1):177-180

Meyling NV, Kristensen KT, Eilenberg J (2011) Below- and aboveground abundance and distribution of fungal entomopathogens in experimental conventional and organic cropping systems. Biol Control 59:180-186

Misra CS, Lamba KS (1929) The cotton whitefly (Bemisia gossypi perda n. sp.). Bull Agric Res 196:7

Mohammed AA, Kadhim JH, Kamaluddin ZNA (2018) Selection of highly virulent entomopathogenic fungal isolates to control the greenhouse aphid species in Iraq. Egypt J Biol Pest Control 28(71):1-7

Mohan L, Thangaraju D, Mohanasundaram M, Jayaraj S (1988) Outbreak of the greenhouse whitefly, Trialeurodes vaporariorum (Westwood) in the Nilgiris. Madras Agric J 75:368-370

Mora MAE, Castilho AMC, Fraga ME (2017) Classification and infection mechanism of entomopathogenic fungi. Arq Inst Biol 84:1-10

Muiizenberg VD, Ervin WB (1980) A history of Greenhouses. Institute for Agricultural Engineering, Wageningen, Netherland

Nagamandla RS, Jha S, Latha NS (2017) Insect pests of tomato and their weather relations under open and cover cultivation. Int J Curr Microbiol Sci 6(9):368375

Navale AV, Nandagude S B, Pawar A G, Ghodke H M and Bhosale A D (2003) Comparative study of capsicum skirting and top covering effect in low cost greenhouse. In Proc. All India Sem. Potential Prospects for Protective Cultivation Institute of Engineers, Ahmednagar, December 12-13, 2003 p.97.

Nazir T, Basit A, Hanan A, Majeed MZ, Qiu D (2019) In vitro pathogenicity of some entomopathogenic fungal strains against green peach aphid Myzus persicae (Homoptera: Aphididae). Agron 9(7):1-12

Ngullie R, Biswas PK (2016) Performance of capsicum under protected and open field cultivation under Mokokchung district of Nagaland. J Crop Improv 7(2): $197-200$

Oliveira M, Henneberry T, Anderson P (2001) History, current status and collaborative research projects for Bemisia tabaci. Crop Prot 20:709-723

Padhi GK, Labani M, Chattopadhyay A, Samanta A (2017) Population dynamics of whitefly (Bemisia tabaci Genn.) in chilli and screening of genotypes against chili leaf curl virus. J Entomol Zool Stud 5(5):104-107

Pappas ML, Migkou F, Broufas GD (2013) Incidence of resistance to neonicotinoid insecticides in greenhouse populations of the whitefly, Trialeurodes vaporariorum (Hemiptera: Aleyrodidae) from Greece. Appl Entomol Zool 48: 373-378

Pekkeriet EJ, Henten EJ, Campen JB (2015) Contribution of innovative technologies to new developments in horticulture. Acta Hortic 1099:45-54

Perdikis D, Kapaxidi E, Papadoulis G (2008) Biological control of insect and mite pests in greenhouse solanaceous crops. European J Plant Sci Biotech 2:125144

Phadke AD, Phadke B (2000) Evaluation of verti-guard along with conventional and non-conventional insecticides and repellents for control of brinjal whitefly, Bemisia tabaci. Pestology 24:28-31
Pilkington LJ, Messelink G, van Lenteren JC, Mottee KL (2010) Protected biological control: biological pest management in the greenhouse industry. Biol Control 52:216-220

Poprawski TJ, Greenberg SM, Ciomperlik MA (2000) Effect of host plant on Beauveria bassiana and Paecilomyces fumosoroseus-induced mortality of Trialeurodes vaporariorum (Homoptera: Aleyrodidae). Environ Entomol 29: 1048-1053

Qin Y, Ying SH, Chen Y, Shen ZC, Feng MG (2010) Integration of insecticidal protein Vip3Aa1 into Beauveria bassiana enhances fungal virulence to Spodoptera litura larvae by cuticle and Per Os infection. Appl Environ Microbiol. 76(14):4611-4618

Ramanujam B, Rangeshwaran R, Sivakmar G, Mohan M, Yandigeri MS (2014) Management of insect pests by microorganisms. Proc Indian Natn Sci Acad $80(2): 455-471$

Rathee M, Dalal P (2018) Emerging insect pests in Indian agriculture. Indian J Entomol 80(2):267-281

Reddy SGE, Kumar NKK (2006) Integrated management of the yellow mite, Polyphagotarsonemus latus (Banks), on sweet pepper grown under polyhouse. J Hortic Sci 1(2):120-123

Romeis J, Naranjo SE, Meissle M, Sheltom AM (2019) Genetically engineered crops help support conservative biological control. Biol Cont 130:136-154

Ruiu L (2018) Microbial biopesticides in agroecosystems. Agron 8(235):1-12

Russell LM (1977) Hosts and distribution of the greenhouse whitefly, Trialeurodes vaporariorum (Westwood), (Hemiptera: Homoptera-Aleyrodidae). Cooperative Plant Pest Report 2:449-458

Sabir N, Singh B (2013) Protected cultivation of vegetables in global arena: a review. Indian J Agric Sci 83:123-135

Sabir N, Sumitha R, Deka S, Bhat M N, Tanwar R K, Singh B A and Chaudhry R (2013) Survey of protected cultivation in major states of India with special reference to pest situations. In: Souvenir and Abstracts, National Seminar on Advances in Protected Cultivation. p 116. Indian Society for Protected Cultivation, New Delhi.

Saito T and Sugiyama (2005) Pathogenicity of three Japanese strains of entomopathogenic fungi against the silverleaf whitefly, Bemisia argentifolii. Appl Entomol Zool 40(1): 169-172.

Sayed SM, Ali EF, Al-Otaibi SS (2019) Efficacy of indigenous entomopathogenic fungus, Beauveria bassiana (Balsamo) Vuillemin, isolates against the rose aphid, Macrosiphum rosae L. (Hemiptera: Aphididae) in rose production. Egypt J Biol Pest Control 29(19):1-7

Scorsetti A C, Humber R A, Gregorio C D, Lo'pezLastra C C (2008) New records of entomopathogenic fungi infecting Bemisia tabaci and Trialeurodes vaporariorum, pests of horticultural crops, in Argentina. Biocontrol 53:787796.

Senthilkumar S, Ashok KR, Chinnadurai M, Ramanathan SP (2018) An economic analysis of capsicum production under protected cultivation in North West Region of Tamil Nadu, India. Int J Curr Microbiol Appl Sci 7(6):2276-2283

Shah DR, Shukla A (2014) Seasonal incidence of spider mite, Tetranychus urticae (Koch) (Tetranychidae: Acari) on gerbera (Gerbera jamesonii) under polyhouse conditions. Pest Manag Hort Ecosyst 20:26-29

Sharma GD, Devi N, Raj D (2006) Monitoring of greenhouse whitefly, Trialeurodes vaporariorum (Westwood) through yellow pan traps and relationship of adult activity with whitefly population on tomato in Himachal Pradesh. Insect Environ. 12(2):85-88

Sharma S, Kooner R, Arora R (2017) Insect pests and crop losses. Breeding Insect Resistant Crops for Sustainable Agriculture. https://doi.org/10.1007/978-981-106056-4_2

Singh A K, Gupta M J and Shrivastva R (2003) Effect of polyhouse on insect-pest incidence, fruit quality and production of vegetable and fruit crops. Proc Frontier Areas of Entomological Research Symp. Pp 163-62. Indian Agricultural Research Institute, New Delhi.

Singh AK, Singh B, Gupta R (2011) Performance of sweet pepper (Capsicum annum) varities and economics under protected and open field cultivation in Uttarakhand. Indian J Agr Sci 81(10):973-995

Singh B (2013) Protected cultivation in India: challenges and strategies. Curr Hortic 1:3-6

Singh H, Joshi N (2020) Management of the aphid, Myzus persicae (Sulzer) and the whitefly, Bemisia tabaci (Gennadius), using biorational on capsicum under protected cultivation in India. Egypt I Biol Pest Control 30:1-9. https:// doi.org/10.1186/s41938-020-00266-5

Skinner M, Parker BL, Kim JS (2014) Role of entomopathogenic fungi. In: Abrol DP (ed) Integrated pest management. Academic Press, Cambridge, pp 169-191 
Sood AK, David BV (2012) The greenhouse whitefly, Trialeurodes vaporarriorum Westwood). In: David BV (ed) The Whitefly or Mealywing Bugs. LAP Lambert Academic Publishing Gmbh \& Co. KG, Germany, pp 147-169

Sood A K, Mehta P K, Verma K S, Sharma K D, Banyal D K and Chandel Y S (2012a) Status of plant protection mechanism under protected cultivation in Himachal Pradesh. Proc Indian Sci Congr. pp 154-155. OUAT. Bhubneswar.

Sood AK, Mehta PK, Verma KS, Sharma KD, Banyal DK and Chandel YS (2012b) Status of plant protection mechanism under protected cultivation in Himachal Pradesh. Proceedings `Indian Science Congress - 2012`at Bhubneswar, January 3-7, 2012, pp 154-155.

Sood AK and Sharma G (2010) Spatial distribution and management of greenhouse whitefly in Himachal Pradesh. Proceedings: National Seminar 'Perspectives and Challenges of Integrated Pest Management for Sustainable Agriculture' at Dr Y. S. Parmar University of Horticulture and Forestry, Nauni w.e.f. November 19-21, 2010`. pp 55.

Sood AK, Singh V, Mehta PK (2018) Current status and management strategies of insect-pests of vegetables crops under protected cultivation in Himachal Pradesh. In: Sanjeev Kumar, Patel N B, Saravaiya S N and Patel B N (ed) Proc Technologies and Sustainability of Protected Cultivation for Hi-Valued Vegetable Crops. Vol 2. Navsari Agricultural University, Navsari, Gujarat, India, pp 339354

Sood AK, Sood S (2005) Seasonal abundance and management of greenhouse whitefly, Trialeurodes vaporariorum (Westwood) on French bean in Himachal Pradesh. Proc 1st Cong Insect Sci:148-150 Punjab Agricultural University, Ludhiana, India

Sood AK, Sood S, Anjana D (2014) Morphometric and annual life cycle of greenhouse whitefly, Trialeurodes vaporariorum (Westwood) in Himachal Pradesh. Himachal J Agric Res 40:50-57

Sood S, Sood AK, Verma KS (2006) Determination of baseline toxicity of some insecticides to greenhouse whitefly, Trialeurodes vaporariorum (Westwood) population from North-Western Indian Himalayas. Pest Manag Hort Ecosyst 12:67-70

Sreedhara DS, Kerutagi MG, Kunnal LB, Dodamani MT (2013) Economics of capsicum production under protected cultivation under protected cultivation in Northern Karnataka. Karnataka J Agric Sci 81(10):973-975

St Leger RJ, Joshi L, Bidochka MJ, Rizzo NW, Roberts DW (1996) Characterization and ultrastructural localization of chitinase from Metarhizium anisopliae, $M$. flavoviride, and Beauveria bassiana during fungal invasion of host (Manduca sexta) cuticle. Appl Environ Microbiol 62(3):907-912

Ullah Ml, Altaf N, Afzal M, Arshad M, Mehmood N, Majeed S, Ali S, Abdullah A (2019) Effects of entomopathogenic fungi on the biology of Spodoptera litura (Lepidoptera: Noctuidae) and its reduviid predator, Rhynocoris marginatus (Heteroptera: Reduviidae). Inter J Insect Sci 11:1-7

van der Kamp RJ, Lenteren JC-v (1981) Do mechanical barriers of the host plant prevent successful penetration of the phloem by whitefly larvae and adults. J Appl Entomol 92:149-159

Van Lenteren JC (2000) A greenhouse without pesticides: fact or fantasy. Crop Prot 19:375-384

Vashisth S (2009) Insect and nematode complex associated with some polyhouse crops. CSK Himachal Pradesh Krishi Vishvavidyalaya, Palampur (Unpublished), $M$ Sc Thesis

Vasicek A, F-de-la R, Paglioni A (2001) Biological and population aspects of Aulacorthum solani (Kalt), Myzus persicae (Sulz) and Macrosiphum euphorbiae (Thomas) (Homoptera :Aphidoidea) on pepper under laboratory cultivation. Boletin de Sanidal Vegetal Plagas 27(4):439-446

Verma AK, Basu D, Nath PS, Das S, Ghatak SS, Mukhopadhyay S (1989) Relationship between the population of whitefly, Bemisia tabaci Genn. (Homoptera: Aleyrodidae) and the incidence of tomato leaf curl virus disease. Indian J Mycol Res 27:49-52

Vidal C, Osborne LS, Lacey LA, Fargues J (1998) Effect of host plant on the potential of Paecilomyces fumosoroseus (Deuteromycotina: Hyphomycetes) for controlling the silverleaf whitefly, Bemisi aargentifolii (Homoptera: Aleyrodidae) in greenhouses. Biol Contr 12:191-199

Vu VH, Hong SI, Kim K (2007) Selection of entomopathogenic fungi for aphid control. J Biosci Bioeng 104(6):498-505

Weintraub PG (2007) Review Integrated control of pests in tropical and subtropical sweet pepper production. Pest Manag Sci 63:753-760

Wraight SP, Carruthers RI, Jaronski ST, Bradley CA, Garza CJ, Wraight SG (2000) Evalution of the entomopathogenic fungi; Beauveria bassiana and Paecilomyces fumosoroseus for microbial control of the silverleaf whitefly, Bemisia argentifolii. Biol Cont 17:203-217
Xu C, Zhang X, Qian Y, Chen X, Liu R, Zeng G, Zhao H, Fang W (2014) A highthroughput gene disruption methodology for the entomopathogenic fungus Metarhizium robertsii. Plos One 9(9):1-7

Xu RM, Zhang Y, Ma WR (1994) The probing and feeding process of the greenhouse whitefly, Trialeurodes vaporariorum Westwood. Entomol Sin 1:67-76

Zhao H, Lovett B, Fung W (2016) Genetically engineering entomopathogenic fungi. Adv Genet. 94:1-27

\section{Publisher's Note}

Springer Nature remains neutral with regard to jurisdictional claims in published maps and institutional affiliations.

\section{Submit your manuscript to a SpringerOpen ${ }^{\circ}$ journal and benefit from:}

- Convenient online submission

- Rigorous peer review

- Open access: articles freely available online

- High visibility within the field

- Retaining the copyright to your article

Submit your next manuscript at $\boldsymbol{\nabla}$ springeropen.com 